\title{
PENGARUH MEDIA KALENDER PINTAR OBAT BEBAS TERHADAP PENGETAHUAN DAN SIKAP DALAM MEWUJUDKAN GEMA CERMAT
}

\section{THE INFLUENCE OF A SMART-FREE DRUG CALENDER MEDIA ON KNOWLEDGE AND ATTITUDE IN MAKING A GEMA CERMAT}

\author{
Fadli ${ }^{1)^{\star}}$, Aura Badarul Alam Haq Faridl Syah ${ }^{2)}$ \\ Akademi Farmasi Yarsi Pontianak \\ Jalan Panglima Aim No. 2 - Pontianak \\ *e-mail: fadliapoteker@yahoo.com
}

Diterima: 31 Mei 2021, Revisi 22 Juni 2021, Diterbitkan : 30 Juni 2021

\begin{abstract}
Along with changes in the lifestyle of people who tend to pay less attention to health, disease development in the community is inevitable. Providing education about medicine through smart calendars to the public can overcome this problem. Calendar is designed to improve thinking skills and stimulate adolescents' thinking, including concentrating and solving problems against changes in knowledge and action. This study aims to determine whether there is an effect of innovative calendar media for learning over-thecounter drugs on knowledge and attitudes in realizing the intelligent community movement using drugs. Were conducted this research with a quantitative survey method by collecting data via a google form. The sampling method uses probability sampling with a simple random sampling technique. Sampling was conducted on 140 adolescents at SMA Negeri 1 Kendawangan, then obtained a sample of 116 respondents. Data analysis used the Kolmogorov-Smirnov test for normality, Wilcoxon test for hypothesis testing of knowledge and attitudes. The level of confidence used is $95 \%$. The results showed an increase in the number of respondents between the pre-test and post-test. With an Asymp.sig (2-tailed) value on knowledge and attitude of 0.000. So it can be concluded that there is an effect of using free drug calendar media on the inside and attitudes of class XI students of SMA Negeri 1 Kendawangan.
\end{abstract}

Keywords: Self-Medication, Gema Cermat, Smart Calendar, Over-the-counter drugs

\begin{abstract}
ABSTRAK
Seiring perubahan pola hidup masyarakat yang cenderung kurang memperhatikan kesehatan, maka berkembangnya penyakit di masyarakat tidak dapat dielakkan lagi. Permasalahan tersebut dapat diatasi dengan memberikan edukasi tentang obat melalui media kalender pintar kepada masyarakat. Kalender dirancang untuk meningkatkan kemampuan berpikir serta merangsang daya pikir remaja termasuk kemampuan berkonsentrasi dan memecahkan masalah terhadap perubahan pengetahuan dan tindakan. Penelitian ini bertujuan untuk mengetahui apakah ada pengaruh media kalender pintar belajar obat bebas terhadap pengetahuan dan sikap dalam mewujudkan gerakan masyarakat cerdas menggunakan obat. Penelitian ini dilakukan dengan metode kuantitatif survey dengan melakukan pengumpulan data melalui google form. Sampel dipilih sebanyak 116 responden siswa di SMA Negeri 1 Kendawangan yang ditentukan dengan dengan teknik simple random sampling. Analisis data menggunakan KolmogorovSmirnov untuk uji normalitas, Wilcoxon-test untuk uji hipotesis pengetahuan dan sikap. Taraf kepercayaan digunakan $95 \%$. Hasil penelitian menunjukkan adanya peningkatan jumlah responden antara pretest dan posttest. Dengan nilai Asymp.sig (2-tailed) pada pengetahuan dan sikap 0,000, maka dapat disimpulkan bahwa terdapat pengaruh penggunaan media kalender obat bebas terhadap pengetahuan dan sikap siswa SMA Negeri 1 Kendawangan kelas XI.
\end{abstract}

Kata kunci: Swamedikasi, Gema Cermat, Kalender Pintar, Obat Bebas 


\section{PENDAHULUAN}

Seiring perubahan pola hidup masyarakat yang cenderung kurang memperhatikan kesehatan, maka berkembangnya penyakit di masyarakat tidak dapat dielakkan lagi. Berkembangnya penyakit ini mendorong masyarakat untuk mencari alternatif pengobatan yang efektif secara terapi dan juga efisien dalam hal biaya. Berkenaan dengan hal tersebut, swamedikasi menjadi alternatif yang diambil oleh masyarakat (Ministry of Health of the Republic of Indonesia, 2007). Pengobatan sendiri atau yang disebut swamedikasi adalah suatu pengobatan sendiri yang dilakukan oleh masyarakat terhadap penyakit yang umum diderita. Masyarakat secara mandiri menggunakan obat-obatan baik obat modern, herbal, maupun obat tradisional yang dijual bebas di pasaran yang bisa didapat tanpa resep dokter dan diserahkan oleh apoteker di apotek (Kemenkes RI, 2015).

Survey Sosial Ekonomi Nasional menunjukkan bahwa lebih dari $66 \%$ masyarakat melakukan pengobatan sendiri. Data World Health Organization menunjukkan sekitar $50 \%$ dari seluruh penggunaan obat tidak tepat dalam peresepan dan sekitar $50 \%$ lainnya tidak digunakan secara tepat oleh pasien (Ihsan et al., 2017). Untuk mengatasi kesalahan dalam swamedikasi, Kementerian Kesehatan membuat program terbaru yakni GEMA CERMAT (Gerakan Masyarakat Cerdas Menggunakan Obat). Gema Cermat dicanangkan sebagai upaya bersama antara pemerintah dan masyarakat melalui rangkaian kegiatan dalam rangka mewujudkan kepedulian, kesadaran, pemahaman dan keterampilan masyarakat dalam menggunakan obat secara tepat dan benar (Kemenkes RI,
2015). Program ini juga bertujuan untuk meningkatkan kemandirian masyarakat dalam memilih, mendapatkan, menggunakan, menyimpan, dan memusnahkan obat secara tepat dan benar, dan meningkatkan penggunaan obat secara rasional (Kemenkes RI, 2015).

Gema Cermat perlu kerjasama dan dukungan dari berbagai pihak agar dapat berjalan dengan baik dan berguna bagi masyarakat. Salah satu cara yang dapat dilakukan untuk mewujudkannya adalah pemberian kalender pintar sebagai media edukasi obat. Kalender pintar memuat informasi indikasi, dosis, waktu pemberian, efek samping, kontraindikasi, perhatian khusus, serta indeks keamanan ibu hamil dan menyusui. Materi dalam kalender disajikan dalam bentuk gambar yang dilengkapi dengan keterangan sehingga memiliki daya tarik tersendiri untuk mempelajarinya. Puspitasari et al., (2019) menyebutkan bahwa penggunaan media kalender penanda menstruasi berpengaruh terhadap peningkatan pengetahuan dan perubahan perilaku WUS dalam menandai tanggal HPHT. Kalender merupakan media promosi yang tepat digunakan karena mudah dijangkau dan praktis, dapat dilihat berulang-ulang oleh keluarga maupun lansia karena kebutuhan pembaca untuk melihat waktu dan adanya daya tarik disertai dengan gambar-gambar yang menarik (Abdul and Susaanti, 2018).

Anak-anak dan remaja berada dalam masa krusial karena kebanyakan praktek swamedikasi biasanya dimulai pada masa remaja, yang merupakan masa belajar di sekolah menengah (Siponen, S 2014). Hasil observasi awal yang dilakukan di SMA Negeri 1 Kendawangan mengindikasikan bahwa banyak siswa yang ketika sakit langsung 
membeli obat di toko obat tanpa memeriksakan diri terlebih dahulu ke dokter.

Berdasarkan latar belakang tersebut, maka perlu dilakukan penelitian tentang "Pengaruh Media Kalender Pintar Belajar Obat Bebas Terhadap Pengetahuan Dan Sikap Dalam Mewujudkan Gerakan Masyarakat Cerdas Menggunakan Obat" untuk melihat serta mengungkapkan pengaruh pemberian kalender pintar terhadap peningkatan pengetahuan dan sikap dalam menggunakan obat bebas pada remaja

\section{METODE}

Penelitian ini merupakan penelitian cross sectional dengan desain penelitian analisis kuantitatif. Penelitian dilakukan pada bulan Februari-April 2021 di wilayah Kendawangan yaitu, SMA Negeri 1 Kendawangan, Kecamatan Kendawangan, Kabupaten Ketapang, Kalimantan Barat.

Populasi penelitian ini adalah para siswa SMAN 1 Kendawangan Kelas XI tahun Angkatan 2019/2020 yang berjumlah 140 orang. Jumlah sampelnya sebanyak 116 responden yang dipilih dengan Teknik Simple Random Sampling. Mereka berusia 15-20 tahun dengan karakteristik tidak memiliki latar belakang pendidikan di bidang kesehatan yang ada di Kecamatan Kendawangan. Tahapan penelitian yang dilakukan adalah pretest, edukasi melalui media kalender dan posttest. Teknik pengumpulan data penelitian ini menggunakan kuesioner yang dibagikan secara online menggunakan google form dengan item pernyataan yang digunakan sebanyak 19. Kuesioner pada penelitian ini dilakukan uji validitas dan reabilitas. Uji validitas dilakukan dengan menggunakan korelasi person product moment sebanyak 11 kuesioner pengetahuan dan 8 kuesioner sikap valid. Uji reabilitasnya dilakukan dengan menggunakan metode cronbach's alpha sebanyak 11 kuesioner pengetahuan dan 8 kuesioner sikap reliabel.

Uji normalitas dikerjakan dengan software SPSS.25. Uji normalitas dilakukan untuk mengetahui apakah data yang diperoleh pada saat penelitian terdistribusi normal atau tidak. Uji normalitas yang digunakan adalah teknik Kolmogorov-Smirnov, karena jumlah responden yang digunakan dalam penelitian ini adalah 116.

\section{HASIL DAN PEMBAHASAN}

Tabel 1. Frekuensi karakteristik responden

\begin{tabular}{cccc}
\hline No & Karakteristik & Frekuensi & Presentase \\
\hline $\mathbf{1}$ & Umur & & \\
& 16 Tahun & 3 & $2,6 \%$ \\
& 17 Tahun & 58 & $50 \%$ \\
& 18 Tahun & 43 & $37,1 \%$ \\
& 19 Tahun & 12 & $10,3 \%$ \\
& Total & 116 & $100 \%$ \\
& Jenis & & \\
$\mathbf{2}$ & Kelamin & & \\
& Laki-Laki & 26 & $22,4 \%$ \\
& Perempuan & 90 & $77,6 \%$ \\
& Total & 116 & $100 \%$ \\
\hline Sumber : data yang diolah, 2021 &
\end{tabular}

Berdasarkan data di atas dapat diketahui bahwa jumlah sampel pada penelitian ini sebagian besar berusia 17 tahun (50\%). Selain itu, diketahui bahwa sebagian besar responden berjenis kelamin perempuan yaitu, sebanyak 90 responden $(77,6 \%)$. 
Tabel 2. Distribusi persentase pengetahuan

\begin{tabular}{|c|c|c|}
\hline Pengetahuar & $\mathbf{N}$ & $\begin{array}{c}\text { Persentase } \\
(\%)\end{array}$ \\
\hline \multicolumn{3}{|c|}{ Pretest } \\
\hline Baik & 4 & 3,45 \\
\hline Cukup & 3 & 2,59 \\
\hline Kurang & 109 & 93,96 \\
\hline Total & 116 & 100 \\
\hline \multicolumn{3}{|c|}{ Post-test } \\
\hline Baik & 100 & 86,21 \\
\hline Cukup & 8 & 6,90 \\
\hline Kurang & 8 & 6,90 \\
\hline Total & 116 & 100 \\
\hline \multicolumn{3}{|c|}{$\begin{array}{l}\text { Sumber : data yang diolah, } 2021 \\
\text { Tabel 3. Distribusi persen }\end{array}$} \\
\hline Sikap & v & $\begin{array}{c}\text { Persentase } \\
(\%)\end{array}$ \\
\hline \multicolumn{3}{|c|}{ Pretest } \\
\hline Baik & 7 & 6,03 \\
\hline Cukup & 2 & 36,21 \\
\hline Kurang & 7 & 57,76 \\
\hline Total & 16 & 100 \\
\hline
\end{tabular}

\begin{tabular}{ccc}
\hline \multicolumn{3}{c}{ Post-test } \\
\hline Baik & 102 & 87,93 \\
Cukup & 14 & 12,07 \\
Kurang & 0 & 0 \\
Total & $\mathbf{1 1 6}$ & $\mathbf{1 0 0}$ \\
\hline Sumber : data yang diolah, 2021
\end{tabular}

Seperti terlihat pada Tabel 2, pengetahuan pada pretest mayoritas responden berada pada kategori kurang yaitu, 93,96\%, sedangkan pada saat posttest, 86,21\% responden diketahui telah mengalami peningkatan pengetahuan pada kategori baik.

Tabel 3 menunjukkan bahwa hasil tingkat sikap pada pretest dari mayoritas responden dikategorikan kurang yaitu, $57,76 \%$. Namun, pada posttest tingkat sikap, 87,93\% responden telah masuk pada kategori baik.

Tabel 4. Uji Normalitas Pengetahuan

Kolmogorov-Smirnov ${ }^{\mathrm{a}} \quad$ Shapiro-Wilk

\begin{tabular}{lrlrrrc}
\cline { 2 - 7 } & Statistic & df & Sig. & Statistic & df & Sig. \\
\hline pretest_pengetahuan & 0,200 & 116 & 0,000 & 0,790 & 116 & 0,000 \\
\hline posttest_pengetahuan & 0,287 & 116 & 0,000 & 0,637 & 116 & 0,000
\end{tabular}

a. Lilliefors Significance Correction

Sumber : data yang diolah, 2021

Tabel 5. Uji Normalitas Sikap

\begin{tabular}{lrrrrrr}
\hline & \multicolumn{3}{c}{ Kolmogorov-Smirnova $^{\mathrm{a}}$} & \multicolumn{3}{c}{ Shapiro-Wilk } \\
\cline { 2 - 8 } & Statistic & \multicolumn{1}{c}{$\mathrm{df}$} & \multicolumn{1}{c}{ Sig. } & Statistic & \multicolumn{1}{c}{ df } & \multicolumn{1}{c}{ Sig. } \\
\hline pretest_sikap & 0,103 & 116 & 0,004 & 0,950 & 116 & 0,000 \\
\hline posttest_sikap & 0,124 & 116 & 0,000 & 0,960 & 116 & 0,002
\end{tabular}

a. Lilliefors Significance Correction

Sumber : data yang diolah, 2021 
Tabel 6. Hasil Uji Wilcoxon Pengetahuan Dan Sikap

\begin{tabular}{|c|c|c|c|c|}
\hline \multicolumn{5}{|c|}{ Ranks } \\
\hline & & $\mathrm{N}$ & Mean Rank & $\begin{array}{l}\text { Sum of } \\
\text { Ranks }\end{array}$ \\
\hline \multirow{4}{*}{$\begin{array}{l}\text { posttest_pengetahuan- } \\
\text { pretest_pengetahuan }\end{array}$} & Negative Ranks & $5^{a}$ & 8,00 & 40,00 \\
\hline & Positive Ranks & $110^{\mathrm{b}}$ & 60,27 & 6630,00 \\
\hline & Ties & $1^{\mathrm{c}}$ & & \\
\hline & Total & 116 & & \\
\hline \multicolumn{5}{|c|}{ a. posttest_pengetahuan < pretest_pengetahuan } \\
\hline \multicolumn{5}{|c|}{ b. posttest_pengetahuan > pretest_pengetahuan } \\
\hline c. posttest_pengetahua & getahuan & & & \\
\hline
\end{tabular}

\begin{tabular}{|c|c|c|c|c|}
\hline \multicolumn{5}{|c|}{ Ranks } \\
\hline & & $\mathrm{N}$ & $\begin{array}{l}\text { Mean } \\
\text { Rank }\end{array}$ & $\begin{array}{l}\text { Sum of } \\
\text { Ranks }\end{array}$ \\
\hline \multirow[t]{4}{*}{ posttest_sikap - pretest_sikap } & Negative Ranks & $6^{a}$ & 9,92 & 59,50 \\
\hline & Positive Ranks & $109^{b}$ & 60,65 & 6610,50 \\
\hline & Ties & $1^{c}$ & & \\
\hline & Total & 116 & & \\
\hline \multicolumn{5}{|l|}{ a. posttest_sikap < pretest_sikap } \\
\hline \multicolumn{5}{|l|}{ b. posttest_sikap > pretest_sikap } \\
\hline c. posttest_sikap = pretest_sikap & & & & \\
\hline
\end{tabular}

\section{Test Statisticsa}

\begin{tabular}{lrr}
\hline & posttest_sikap - pretest_sikap & \multicolumn{2}{c}{$\begin{array}{c}\text { posttest_pengetahuan - } \\
\text { pretest_pengetahuan }\end{array}$} \\
\hline Z & $-9.147^{\mathrm{b}}$ & $-9.221^{\mathrm{b}}$ \\
\hline Asymp. Sig. (2-tailed) & 0,000 & 0,000 \\
\hline a. Wilcoxon Signed Ranks Test & & \\
\hline b. Based on negative ranks. & & \\
Sumber : data yang diolah, 2021 & &
\end{tabular}

Pada hasil uji normalitas didapatkan nilai Sig pengetahuan baik pretest maupun posttest sebesar 0,000, sedangkan pada sikap nilai Sig yang didapat pada pretest adalah 0,004 dan posttest adalah 0,000. Berdasarkan hasil ini, maka dapat disimpulkan bahwa data tersebut tidak berdistribusi normal karena nilai Sig yang didapat $<0,05$. Setelah diketahui bahwa distribusi data tidak normal, maka analisis data yang dapat langsung dilakukan adalah menggunakan uji hipotesis Wilcoxon.

Dapat dilihat pada Tabel 6, bahwa terdapat perbedaan hasil nilai antara pretest dan posttest. Berdasarkan hasil uji Wilcoxon, nilai Asymp.sig (2-tailed) pada pengetahuan dan sikap bernilai 0,000 . Oleh karena itu, $\mathrm{H}_{0}$ ditolak $\mathrm{H}_{1}$ diterima. Rerata pengetahuan sebelum dan setelah edukasi dengan booklet berbeda sebesar 4,93 ( $p=0,022)$. Ini menunjukkan bahwa ada perbedaan nilai rata-rata pengetahuan dan sikap pada data sebelum dan sesudah pemberian kalender.

Hasil diatas didukung oleh Puspitasari et al (2019) yang menyebutkan bahwa penggunaan media kalender penanda menstruasi berpengaruh terhadap peningkatan pengetahuan dan perubahan perilaku 
WUS (wanita usia subur) dalam menandai tanggal HPHT (hari pertama haid terakhir).

Selain media kalender, terdapat beberapa media lain yang digunakan untuk meningkatkan pengetahuan dan sikap responden. Meidiana, Simbolon, \& Wahyudi (2018) mengatakan bahwa media audio visual dan leaflet memiliki pengaruh edukasi terhadap peningkatan pengetahuan remaja overweight dan obesitas. Nurul Riau Dwi Safitri (2016) menambahkan bahwa edukasi melalui booklet meningkatan skor pengetahuan saat posttest.

Menurut Azwar (2008), output sikap akan sangat bergantung pada setiap individu. Apabila individu tersebut tertarik, maka ia akan mendekat dan apabila tidak suka, maka ia akan merespon sebaliknya. Marisa and Nuryanto (2014) menyebutkan bahwa sikap dipengaruhi oleh berbagai faktor, yang salah satunya adalah pendidikan atau edukasi. Pendidikan merupakan salah satu alat untuk menghasilkan perubahan pada diri manusia karena melalui pendidikan manusia akan dapat mengetahui segala sesuatu yang tidak atau belum diketahui sebelumnya.

Media juga merupakan salah satu faktor yang mempengaruhi sikap seseorang. Media bermanfaat menimbulkan minat sasaran, merangsang sasaran untuk meneruskan pesan pada orang lain, dan memudahkan penyampaian informasi (Suiraoka, 2012). Selain itu, peningkatan sikap juga dikarenakan oleh peningkatan pengetahuan. Peningkatan pengetahuan dan sikap ini diperoleh dari proses belajar dengan memanfaatkan semua alat indera, dimana $13 \%$ dari pengetahuan diperoleh melalui indera dengar dan 35-55\% melalui indera pendengaran dan penglihatan (Bertalina,
2015).

Pengetahuan adalah hasil dari informasi yang kemudian diperhatikan, dimengerti, dan diingat. Informasi dapat bermacam-macam bentuknya baik pendidikan formal maupun informal, seperti membaca surat kabar, mendengar radio, menonton TV, percakapan sehari-hari, dan pengalaman hidup lainnya (Notoatmodjo, S., 2010).

Faktor-faktor yang dapat mempengaruhi pengetahuan menurut Mubarak, W. I (2007) adalah umur, pendidikan, pekerjaan, lama bekerja, pengalaman, kebudayaan dan informasi. Proses belajar yang menumbuhkan sikap kritis dapat meningkatkan pengetahuan responden secara bermakna. Green \& Kreuter (2000) berpendapat bahwa proses belajar yang melibatkan peserta didik secara aktif akan menghasilkan pengetahuan yang lebih mantap dan dapat bertahan lama. Proses perubahan sikap merupakan suatu hasil belajar yang dapat terjadi apabila ada stimulus (pengetahuan) pada aspek kognitif seseorang.

\section{KESIMPULAN}

Penelitian ini menemukan adanya peningkatan pengetahuan dan sikap responden secara signifikan $(p<0,05)$. Hasil uji menunjukkan bahwa diketahui nilai Asymp.sig (2-tailed) pada pengetahuan dan sikap adalah 0,000 atau hipotesis diterima. Ini berarti ada perbedaan antara hasil pengetahuan dan sikap siswa mengenai obat bebas untuk pretest dan posttest, dan terdapat pengaruh penggunaan media kalender obat bebas terhadap pengetahuan dan sikap para siswa SMA Negeri 1 Kendawangan kelas XI. 


\section{REKOMENDASI}

Penggunaan kalender pintar obat bebas dapat dijadikan salah satu media untuk meningkatkan pengetahuan dan perubahan sikap masyarakat menjadi lebih peduli, sadar, paham dan terampil dalam menggunakan obat secara tepat dan benar. Penggunaan media kalender pintar ini dapat menjadi upaya alternatif untuk mendukung program terbaru pemerintah, yakni GEMA CERMAT (Gerakan Masyarakat Cerdas Menggunakan Obat).

\section{UCAPAN TERIMAKASIH}

Penulis mengucapkan terima kasih kepada bapak Fadli., S.Farm., Apt. MM, dosen pembimbing, yang telah memberikan arahan dalam menulis karya tulis ilmiah ini. Ucapan terima kasih juga disampaikan kepada semua pihak yang telah berperan dalam penelitian.

\section{DAFTAR PUSTAKA}

Abdul, Y., \& Susaanti, E. (2018). Pengaruh Pendidikan Kesehatan Dengan Media Kalender Terhadap Peningkatan Pengetahuan Lansia Tentang Penatalaksanaan Rematik. 9, 88-98.

Azwar, S. (2008). Sikap Manusia Teori dan Pengukurannya. Yogyakarta: pustaka belajar.

Bertalina. (2015). Pengaruh Promosi Kesehatan Terhadap Peningkatan Pengetahuan Tentang Gizi Seimbang Pada Siswa Sekolah Dasar Negeri Di Kecamatan Rajabasa Kota Bandar Lampung. Jurnal Kesehatan, 6(1), 56-63.

Green, L. W., Kreuter, M. W. (2000). Health Promotion Planning: An Educational and Environtmental Approach, Edisi 2. California: Mayfield Publishing Company.

Ihsan, S., Sabarudin, Leorita, M.,
Syukriadi, A. S. Z., \& Ibrahim, M. H. (2017). Evaluasi Rasionalitas Penggunaan Obat Ditinjau dari Indikator Peresepan Menurut World Health Organization ( WHO ) di Seluruh Puskesmas Kota Kendari Tahun 2016. Jurnal MEDULA, 5(1), 402-409.

Kemenkes RI. (2015). Buku Kesehatan lbu dan anak. Kemenkes RI.

Marisa, M., \& Nuryanto, N. (2014). Pengaruh Pendidikan Gizi Melalui Komik Gizi Seimbang Terhadap Pengetahuan Dan Sikap Pada Siswa Sdn Bendungan Di Semarang. Journal of Nutrition College, 3(4), 925-932. https://doi.org/10.14710/jnc.v3i4.69 11

Meidiana, R., Simbolon, D., \& Wahyudi, A. (2018). Pengaruh Edukasi melalui Media Audio Visual terhadap Pengetahuan dan Sikap Remaja Overweight. Jurnal Kesehatan, 9(3), 478.

https://doi.org/10.26630/jk.v9i3.961 Ministry of Health of the Republic of Indonesia. (2007). National guideline for the control of tuberculosis (Pedoman nasional penanggulangan tuberkulosis). 119.

Mubarak, W. I. (2007). Promosi Kesehatan Sebuah Pengantar Proses Belajar Mengajar dalam Pendidikan. Yogyakarta: Graha IImu.

Notoatmodjo, S. (2010). Ilmu Perilaku Kesehatan. Jakarta: Rineka Cipta.

Nurul Riau Dwi Safitri, D. Y. F. (2016). Pengaruh Edukasi Gizi Dengan Ceramah Dan Booklet Terhadap Peningkatan Pengetahuan Dan Sikap Gizi Remaja Overweight. Journal of Nutrition College, 5(4), 374-380. https://doi.org/10.14710/jnc.v5i4.16 
438

Puspitasari, N. A., Sastramihardja, H. S., \& Mahwati, Y. (2019). Pengaruh Kalender Penanda Menstruasi Terhadap Peningkatan Pengetahuan dan Perubahan Perilaku Wanita Usia Subur Dalam Menandai Tanggal Hari Pertama Haid Terakhir Changing Behaviour of Women of Childbearing Age in Marking. Jurnal Sistem Kesehatan, 5(71), 166-169.

Siponen, S. (2014). Children's Health, Self-Care and the Use of SelfMedication. University of Eastern Finland: Dissertations in Health Sciences.

Suiraoka IP, S. I. (2012). Media Pendidikan Kesehatan. Yogyakarta: Graha IImu. 